|Araştırma Makalesi / Research Article |

\title{
Öğretmen Adaylarının Yaşam Boyu Öğrenme Eğilimleri İle Kütüphane Alışkanlıklarının Incelenmesi ${ }^{1}$
}

\section{Investigation of Library Habits with Living Dimension Learning Tendencies of Teacher Candidates}

\author{
Nilgün Yenice ${ }^{2}$, Özden Demircioğlu Faydalıgül ${ }^{3}$, Neslihan Yavaşoğlu ${ }^{4}$
}

\begin{abstract}
Anahtar Kelimeler
yaşam boyu öğrenme eğilimi

kütüphane alışkanlıkları

öğretmen adayları
\end{abstract}

\section{Keywords}

lifelong learning

tendency

library habits

teacher candidates

\section{Başvuru Tarihi/Received \\ 11.7.2019}

Kabul Tarihi /Accepted

4.11.2019
Öz

Bu çalışmanın amacı, öğretmen adaylarının kütüphane kullanma alışkanlıklarının yaşam boyu öğrenme eğilimleri üzerindeki etkisinin incelemesidir. Tarama modelinde gerçekleştirilen bu araştırma toplam 692 öğretmen adayının katılımıyla gerçekleştirilmiştir. Araştırmada, Coşkun Diker (2009) tarafından geliştirilen "Yaşam Boyu Öğrenme Eğilimleri Ölçeği" ile öğretmen adaylarıın kütüphane alışkanlıklarını belirlemek amacıyla araştırmacılar tarafından hazırlanmış bilgi formu kullanılmıştır. Elde edilen verilerin analizinde öğretmen adaylarıın Yaşam Boyu Öğrenme Eğilimi Ölçeği'nden elde edilen puanların kütüphane alışkanlıklarına göre anlamlı bir farklılık gösterip göstermediğini belirlemek için Kruskal Wallis $\mathrm{H}$-testi kullanılmıştır. Aynı zamanda Kruskal Wallis H-testi sonucunda elde edilen anlamlı farkılıkların istatistiksel açıdan hangi gruplar arasında olduğunu belirlemek amacıyla ikili gruplar arasında Mann Whitney U-testinden yararlanılmıştır. Elde edilen sonuçlara göre, öğretmen adaylarının yaşam boyu öğrenme eğilimlerinin; kütüphaneyi kullanma sıklığına, okudukları kitap sayısına, kütüphaneyi kullanmayı engelleyen faktörlere göre değişim gösterdiği tespit edilmiştir. Elde edilen bu sonuçlar doğrultusunda yaşam boyu öğrenme eğilimi ile kütüphane alışkanlıklarının tüm öğrenim kademelerinde yüksek düzeye getirilebilmesine yönelik uygulamalar yapılması önerilebilir.

\section{Abstract}

The purpose of this study is to examine the effect of teacher candidates' habits of library use on lifelong learning tendencies. This survey, conducted in the screening model, was conducted with the participation of a total of 692 teacher candidates. "Lifelong Learning Trends Scale" developed by Coşkun Diker (2009) used information form prepared by researchers to determine the library habits of prospective teachers. In the analysis of obtained data, Kruskal Wallis $\mathrm{H}$-test was used to determine whether the scores of prospective teachers' lifelong learning tendency scale were significantly different according to library habits. Mann-Whitney U-test was used between the two groups to determine statistically significant differences among the Kruskal Wallis $\mathrm{H}$-test results. According to the results obtained, the life-long learning tendencies of the teacher candidates; the frequency of using the library, the number of books they read, and the factors that prevent them from using the library. In the direction of these results, it can be suggested that applications for lifelong learning tendency and high level of library habits in all learning stages can be suggested.

\footnotetext{
${ }^{1}$ Bu çalışma 1-3 Şubat 2018 tarihleri arasında Adnan Menderes Üniversitesi Davutlar Kampüsü Kuşadası'nda düzenlenen XV'th International Association of Social Science Research Kongresi'nde sunulan sözlü bildirinin geliştirilmiş halidir.

${ }^{2}$ Aydın Adnan Menderes Üniversitesi, Eğitim Fakültesi, Matematik ve Fen Bilimleri Eğitimi Bölümü, Aydın, TÜRKiYE; http://orcid.org/0000-0002-7935-3110

${ }^{3}$ Aydın Adnan Menderes Üniversitesi, Kütüphane ve Dokümantasyon Daire Başkan V., Aydın, TÜRKiYE; http://orcid.org/0000-0002-7050-2060

${ }^{4}$ Gönül Özgün Kişisel Gelişim Kursu, Aydın, TÜRKiYE; http://orcid.org/0000-0001-9360-0715
} 


\section{Extended Abstract}

\section{Introduction}

The aim of the study is to analyse the effects of pre-service teachers' library use habits on their life-long learning activities. In parallel to this aim the study attempts to respond the following research questions:

1. Do pre-service teachers' library use habits have any significant effects on their life-long learning activities?

2. Do the goals of pre-service teachers' in library use have any significant effects on their life-long learning activities?

3. Do pre-service teachers' reading habits have any significant effects on their life-long learning activities?

4. Do the factors which negatively affect pre-service teachers' reading habits have any significant effects on their life-long learning activities?

\section{Method}

The study is a descriptive study in which a scanning model is employed. The scanning model is one of the research models which aim at descripting a past situation or a present situation as it is (Karasar, 2014).

\section{Participants}

The participants of the study are pre-service teachers attending a public university in the western region of Turkey during the academical year of 2016-2017. More specifically, the participants were attending the following departments: science teaching, pre-school education, educational guidance, classroom teaching, computer and instructional technology education and social studies teaching.

\section{Data Collection Tool}

The data of the study were collected using the "scale on life-long learning" developed by Diker Coşkun (2009). It is a six-point Likert scale which is composed of twenty-seven items. Of these items fifteen items are negative statements whereas the remaining twelve items are positive ones. These items are under four dimensions. Two of these dimensions are positive and the other two are negative. The positive dimensions are named as follows: "motivation concerning life-long learning" and "persistence". The negative dimensions of the scale are as follows: "lack of learning organization" and "lack of curiosity".

The original Cronbach Alpha reliability of the scale was found to be .89. In the current study it was found to be .70. In addition to this scale, an information form regarding the participants' library use habits was also used to gather the data. This form was developed by the authors.

\section{Result and Discussion}

$\mathrm{Bu}$ The findings of the study indicate that the scores of the participants from the scale on life-long learning and from its dimensions, namely motivation, lack of learning organization and lack of curiosity significantly vary based on the variable of the frequency of library use. More specifically, it is found that the frequency of library use has both positive and negative effects on the participants' life-long learning activities. One of the reasons for negative effects of the library use frequency on life-long activities can be the fact that this habit is not acquired from early ages. The other reason can be that in recent years the use of technology is dominant in accessing information. On the other hand, the library use habits have positive effects on individuals' thinking styles, their personality and their life-long learning activities (Yılmaz, 2002).

It is also found that the participants' total scale scores and the scores of the dimensions except for those of "lack of curiosity" and "persistence" significantly vary based on the variable of the goals in using library. In other words, those participants who go to library for using Internet have higher scores from the scale on life-long learning activities and from the dimensions of motivation and lack of learning organization. It seems to be a result of the technological advances. In recent times advances in technology directly affect and change the individual characteristics. In other words, due to such developments in technology individuals prefer to access information through Internet instead of using traditional information sources. Another reason seems to be related to the fact that the use of technology in educational programs and in instructional settings has become common. It can be argued that those individuals, who employ Internet to access information, make research and do homework assignments during their formal education period use technology-based ways in nearly all aspect of their future life. Therefore, these participants prefer to use Internet to access information instead of using books and other traditional ways of accessing information.

The other finding of the study is that the participants' scores from the scale on life-long learning activities and from its dimensions except for the dimension of persistence are significantly affected by the factors that have negative effects on reading. More specifically, the scores from the scale as a whole and from the dimension of motivation of the participants who reported that they cannot find enough time to read books are found to be higher. The scores from the scale as a whole and from the dimension of lack of curiosity of the participants who reported that they cannot find enough time to read books are found to be higher. The scores from the scale as a whole are found to be higher among the participants who reported that reading is not an interesting activity for them. The major factors reported by the participants as an inhibitive factor for reading include the lack of 
time for reading, work load and considering reading as an unattractive activity. In order to reduce the negative effects of such factors on reading the educational programs may be expanded to include reading activities. Gönen et. al. (2004) found that for both male and female students the reading books as a leisure time activity is preferred with the rate of $49,8 \%$. On the other hand, Çetinkaya (2004) concluded that students mostly watch television during their free time (24,2\%).

The studies on the correlations between pre-service teachers' life-long learning activities and their library use habits are not much common. Therefore, it is safe to argue that this study significantly contributes to the field. 
GiRiş

Günümüz bilim ve teknoloji alanındaki hızlı değişimler nedeniyle bazı alanlarda var olan bilgiler, kısa sürede güncelliğini yitirmektedir. İçinde bulunduğumuz dönemde bilginin, hızı bir şekilde değişmesi, gelişmesi ve yayılmasından dolayı bu çağa bilgi çağı denilmektedir. Bilgi toplumunda yaşayan bireyler, hayatın her alanında kendini geliştirme, yenileme, değişimlere çabuk adapte olma, güncel gelişmeleri takip etme ve yaşam boyu öğrenme gibi becerilere sahip olmalıdır (Odabaş, Odabaş ve Polat, 2008). Dolayısıyla günümüzde gelişmiş birey ve gelişmiş bir toplum olabilmenin temel gereklilikleri; bilgiyi araştırma, bilgiye ulaşabilme, bilgiyi yapılandırma, üretme ve yayabilme yeterliklerine sahip olmaktır. Bu nedenle hayatın her alanında kendini geliştiren ve yaşam boyu öğrenen bireylere ihtiyaç duyulmaktadır (Bagnall, 2006; Kaya, 2010). Yaşam boyu öğrenme, 1970'li yıllara kadar mesleki eğitim ile ilgili bir süreç olarak ele alınmıştır (Koç, 2007). Buna karşın son yıllarda çağın gerekliliği haline gelmiş ve toplumun tüm kesimlerini ve eğitim sisteminin bütün kademelerini kapsayan bir süreç olarak vurgulanmaya başlamıştır (Kılıç, 2014; Uysal, 2009). Okullarda verilen eğitim ile bir problemin çözümüne yönelik bilgiler bireye aktarılmaktadır. Bireyin günlük yaşamında karşılaştığı problemlere çözüm yolu bulması için bilginin kullanılması noktasında bilgiyi işlevselleştirme yönünden aksaklıklar yaşanmaktadır. Bu durum yaşam boyu öğrenmenin gerekliliğini ön plana çıkarmaktadır. Yaşam boyu öğrenme farklı kaynaklarda hayat boyu öğrenme, sürekli öğrenme veya sınırsız öğrenme gibi değişik şekillerde adlandırılmaktadır (Ersoy ve Yılmaz, 2009). Yaşam boyu öğrenme kavramına ait farklı adlandırmalar olduğu gibi çeşitli tanımlamalar da bulunmaktadır. Bu tanımlamalara bakıldığında; Kulich (1982) yaşam boyu öğrenmeyi, bireye yaşamı boyunca sürekli olarak eğitim sunulması ve bireyin bu eğitimd en yararlanması olarak ele alırken, Karakuş (2013) ise yaşam boyu öğrenmeyi istendik davranış ve olumlu özellikler edinme süreci olarak tanımlamaktadır. Ersoy ve Yılmaz, (2009) yaşam boyu öğrenmeyi, resmi ya da resmi olmayan bir durum için belirli bir amaca yönelik veya rastgele bilgi ve beceri geliştirme faaliyetlerinin tümü şeklinde ifade etmektedir. Yaşam boyu öğrenme bireylerin yaşamları boyunca edindikleri bilgi, beceri ve görüşleri geliştiren, edinilen bu yeterliklerin yaşam boyunca hayatın her alanında uygulanmasını sağlayan çok yönlü ve devamlı öğrenme etkinlikleridir (Berberoğlu, 2010; Candy, 2003; Rausch, 2003; Thompson, 2001). Tanımlarda da görüldüğü gibi yaşam boyu öğrenme kavramında önemle vurgu yapılan ortak beceriler bulunmaktadır. Devlet Planlama Teşkilatı Özel İhtisas Komisyon Raporu'nda (2006) tanımlardaki ortak noktalar şu şekilde belirtilmiştir:

- Eğitim ve öğretimin etkisine inanma,

- Her bireyin eğitim fırsatlarından yararlanması,

- Eğitim ve öğretim süreci dışındaki öğrenmenin öneminin kabul edilmesi,

- Yaşam boyu öğrenme ve geleneksel öğretim yöntemlerin ayırt edilmesi,

- Öğrenmenin her bireye özgü, bireysel farklılıkları dikkate alınarak tasarlanması,

- Yaşam boyu öğrenmenin, geleneksel öğrenme yaklaşımına alternatif olması şeklindedir.

Bu becerilerin yanı sıra bilgi okuryazarlığı kavramı da yaşam boyu öğrenen, öğrenmeyi öğrenen bireylerin oluşmasında edinilmesi gereken en temel becerilerden biridir. Bilgi okuryazarlığı bu hedefe ulaşmak için hem bir araç hem de yaşam boyu öğrenme sürecinin girdisi ve ürünüdür (Ersoy ve Yılmaz, 2009; Gürdal, 2000; Kurbanoğlu, 2010). Genel anlamıyla okuryazarlık, temel bir insan hakkıdır ve son dönemde tüm toplumun vazgeçilmez bir gereksinimi halini almıştır (Yıldız, 2013). Bilgi okuryazarlığı ise bilgi ihtiyacını fark etme, bilgi ihtiyacını tanımlama, bilgiyi arama yöntemlerini oluşturma, bilgi kaynaklarına ulaşma, ulaşılan doğru kaynakları ayırt etme, bilgiyi çözümleme, yorumlama ve değerlendirme etkinliklerinin etkili bir biçimde gerçekleştirilmesidir (Demiralay ve Karadeniz, 2008). Milli Eğitim Bakanlığı'na (2017) göre yaşam boyu öğrenmenin amacı, bireylerin bilgi çağına uyum sağlamaları ve bu toplumda yaşamlarını daha verimli hale getirebilmeleri için ekonomik ve sosyal hayatın tamamına aktif bir şekilde katılımlarına imkân tanımaktır. Bu nedenle yaşam boyu öğrenme becerisinin devamlılığını sağlamak için okul hayatından sonra devam eden süreçte çeşitli öğrenme alışkanlıkları geliştirilmelidir. Bu hususta bilgi birikimi elde etmede ve öğrenmeyi geliştirmede akla ilk gelen unsurlar kitap ve kütüphanelerdir. Bireylerin sahip oldukları kütüphane kullanma ve okuma alışkanlıkları yaşam boyu öğrenme konusunda büyük öneme sahiptir. Kavram olarak alışkanlık, iç ve dış etkenlerle davranışların tekrarlanması, sürekli benzer şekilde gerçekleşmesi sonucu ortaya çıkan koşullanmış davranış biçimidir (TDK, 1992). Okuma kavramı; harfleri, sözcükleri tanımak ve bunların anlamlarını kavramak (Göğüs, 1978) ya da bilişsel davranışlarla psikomotor becerilerin ortak çalışmasıyla, yazılı sembollerden anlam çıkarma etkinliği şeklinde tanımlanmaktadır (Demirel, 1999). Okuma faaliyeti, beceri ve alışkanlık kazanma ile okuduğunu anlama ve değerlendirme becerisi kazanma olmak üzere iki temel faktörden oluşur (Belet, ve Yaşar, 2007). Okuma alışkanlığı, bireyin okumayı bir ihtiyaç ve eğlence kaynağı olarak algılaması sonucu, okuma faaliyetini yaşam boyu sürekli ve düzenli bir biçimde gerçekleştirmesidir (Doğanay, 2001). Okumanın alışkanlık hâline gelmesi, onun bir ihtiyaç olarak görülmesine bağlıdır. Bu durumun farkında olma; aile, öğretmen ve okul tarafından yapılacak çalışmalar ile kitaba ulaşma ve çevredeki kütüphane imkânlarıyla bağlantılıdır (Özbay, 2007).

Okuma alışkanlığının tanımlanmasında kullanılan temel ölçütleri Dökmen (1990) şu şekilde belirtmiştir:

- Okuyucunun hangi tür yayınlar okuduğu,

- Okuma sıklığı, hangi türlere ilgi duyduğu,

- Sürekli olarak ne kadar okuyabildiği,

- Okuduğu kitap ve kaynakları hangi yolla elde ettiği,

- Kitap okurken farklı bir uğraş ile ilgilenip ilgilenmediği şeklindedir. 
Konu ile ilgili olarak Coşkun (2007) lise öğrencileri ile yapmış olduğu çalışmasında, bazı sosyoekonomik faktörler (aile gelir düzeyi, kardeş sayısı, anne - baba eğitim düzeyi vb) ve öğrencinin çalışma ortamına ilişkin bazı faktörlerin (kişisel bir odanın ve çalışma masasının olup olmaması, oturduğu evin ısınma şekli vb) incelediği çalışmasında öğrencilerin okuma hızı ve anlama düzeylerinde anlamlı farklılıklar oluştuğunu tespit etmiştir. Yapılan araştırmalar, erken dönemde okuma alışkanlığı kazanan bireylerin kelime hazinesinin ve düşünme yeteneğinin arttığını, buna bağlı olarak yaratıcı düşünme, dinleme, konuşma yeteneğinin geliştiğini belirtmektedir. Düşünen, yaratıcı fikir üreten, yaşam boyu öğrenen bireylerin yetiştirilebilmesi için, çocukluk çağında kitap okuma alışkanlığı kazandırılmalıdır.

Yaşam boyu öğrenme ve okuma alışkanlığının gelişmesinde etkili olan bir diğer faktör ise kütüphane alışkanlığıdır. Kütüphane kurumu; zamanla bilginin toplanması, düzenlenip-saklanması ve kullanıma sunulması gibi ihtiyaçlardan dolayı oluşmuştur. Kütüphaneler, toplumun bilgi ve kültür birikimleridir. Bu nedenle kütüphanelerin günlük hayat ve eğitime önemli katkıları vardır. Kütüphaneler; bilimin ilerlemesine, bilginin artmasına ve toplumların çağdaş düzeye erişmesine katkıda bulunacak bireylerin, kitap okuma ihtiyaçlarının karşılanmasını, onlarda kitaba olan ilgiyi artırarak okuma kültürünün benimsenmesini ve kütüphane kullanma alışkanlığının oluşmasını sağlarlar. Kavram olarak kütüphane kullanma alışkanlığı incelendiğinde, bireyin kütüphaneden çeşitli amaçlarla ve belirli aralıklarla yararlanması olarak ifade edilmektedir (Kurulgan ve Çekerol, 2008). Kütüphane kullanma alışkanlığında önemli olan kavramlar süreklilik ve düzenliliktir. Bu iki kavram kütüphane kullanma sayısı temel alınarak değerlendirilmektedir (Kurulgan ve Çekerol, 2008).

Amerikan Kütüphane Derneği'nin (American Library Association-ALA) önermiş olduğu kütüphane kullanım sıklıkları incelendiğinde, genel olarak aşağıdaki düzeyler belirlenmiştir (ALA, 1978):

- Düşük düzeyde alışkanlık: Yılda 1-5 defa kütüphane kullanma

- Orta düzey alışkanlık: Yılda 6-11 defa kütüphane kullanma

- Yüksek düzeyde alışkanlık: Yılda 12 defa ve daha fazla kütüphane kullanma

Genel olarak bu alışkanlıklar; bireyde zekâ gelişimi, başarının arttırılması, dil ve iletişim becerisi edinme, etkin ve sosyal bir kişilik oluşturma, yaşam boyu öğrenmeyi geliştirme gibi alanlarda büyük öneme sahiptir (Yılmaz, 2002). Bu açıdan, yaşam boyu öğrenme faaliyetleri, bazı yeterliklere sahip olabilme, beceri edinimi ve okul dışında da eğitim gibi kavramları kapsamakta, öğrenmeyi hayatın her yerinde ve alanında tüm yaşam boyu devam edecek bir sürece dönüştürmektedir. Öğretim programlarında bu süreçte de en etkili rol oynayan faktörlerin kitap ve kütüphaneler olduğu vurgulanmaktadır. Öğrencilerin kütüphane kullanım alışkanlıklarının Milli Eğitim Bakanlığı'nın (2017) belirlediği beceriler arasında yer alan yaşam boyu öğrenme eğiliminin kazanılmasında önemli rol oynadığı düşünülmektedir. Kütüphane kullanım alışkanlığı olan bireylerin yaşam boyu öğrenen, kendini sürekli çağın gerekleri doğrultusunda geliştiren bireyler olduğu düşünülmektedir. Ayrıca MEB'in belirlediği becerilere sahip olan ve bu becerileri yapılandırarak geniş kitlelere yayabilecek kaynak olarak, eğitim-öğretim sisteminin temel öğesi olan öğretmenlerin yaşam boyu öğrenme becerilerine odaklanmaktadır (Field, 2010; Soran, Akkoyunlu ve Kavak, 2006). Bu nedenle, öğretmen adaylarının sahip oldukları kütüphane alışkanlıklarının yaşam boyu öğrenme eğilimleri üzerindeki etkisinin incelenmesi büyük bir öneme sahiptir. Alan yazın incelendiğinde yaşam boyu öğrenme eğilimi (Atik Kara ve Kürüm, 2007; Bağcl, 2007; Budak, 2009; Haseski, Şahin, Yılmaz ve Erol, 2014; Selvi, 2011; Tortop, 2010) ve kütüphane alışkanlıklarını inceleyen (Agaja, 1992; Bekar, 2005; Dengiz ve Yılmaz, 2007; Keleş, 2006) farklı çalışmalara rastlanılmıştır. Ancak, öğretmen adaylarının kütüphane alışkanlıklarının yaşam boyu öğrenme eğilimlerine etkisinin araştırıldığı çalışmalara ülkemizde rastlanılamamıştır. Dolayısıyla bu çalışma ile öğretmen adaylarının kütüphane kullanma alışkanlıklarının yaşam boyu öğrenme eğilimleri üzerindeki etkisinin incelemesi amaçlanmaktadır. Bu amaçla, aşağıdaki araştırma problemlerine cevap aranmıştır:

1. Öğretmen adaylarının kütüphaneyi kullanma sıklıklarının yaşam boyu öğrenme eğilimleri üzerinde anlamlı bir etkisi var midır?

2. Öğretmen adaylarının kütüphaneyi kullanma amaçlarının yaşam boyu öğrenme eğilimleri üzerinde anlamlı bir etkisi var midır?

3. Öğretmen adaylarının kitap okuma sıklıklarının yaşam boyu öğrenme eğilimleri üzerinde anlamlı bir etkisi var mıdır?

4. Öğretmen adaylarının kitap okumasını engelleyen faktörlerin yaşam boyu öğrenme eğilimleri üzerinde anlamlı bir etkisi var midır?

İlgili alan yazında öğretmen adaylarının yaşam boyu öğrenme eğilimleri ve kütüphane alışkanlıklarını inceleyen herhangi bir çalışmaya rastlanılamamıştır. Araştırmanın bu noktada alan yazına katkı sağlayacağı söylenebilir.

\section{YÖNTEM}

\section{Araştırma Deseni}

Bu araştırma betimsel nitelikte olup, tarama modeli kullanılmıştır. Tarama modeli, geçmişte ya da halen var olan bir durumu var olduğu şekliyle betimlemeyi amaçlayan araştırma modelidir. Araştırmaya konu olan olay, birey veya nesne, kendi koşulları içinde ve var olduğu haliyle tanımlanmaya çalışılır (Karasar, 2014). 


\section{Çalışma Grubu}

Araştırmanın çalışma grubunu, 2016-2017 akademik yılında Türkiye'nin batı bölgesinde yer alan bir ilde bulunan bir üniversitenin eğitim fakültesinde öğrenim görmekte olan toplam 662 öğretmen adayı oluşturmaktadır. Bu öğrencilere ilişkin detaylı bilgilere Tablo 1'de yer verilmiştir.

Tablo 1. Öğretmen adaylarına ilişkin demografik özellikler

\begin{tabular}{|c|c|c|c|}
\hline Değişkenler & Kategori & $\mathrm{N}$ & $\%$ \\
\hline \multirow{2}{*}{ Cinsiyet } & Kız & 455 & 68.1 \\
\hline & Erkek & 207 & 31.9 \\
\hline \multirow{4}{*}{ Sınıf Düzeyi } & 1.sinıf & 157 & 23.7 \\
\hline & 2.sınıf & 154 & 23.3 \\
\hline & 3.sınıf & 170 & 25.7 \\
\hline & 4.sınıf & 181 & 27.3 \\
\hline \multirow{6}{*}{ Öğrenim Görülen Bölüm } & Sınıf Öğretmenliği & 127 & 19.2 \\
\hline & Fen Bilgisi Öğretmenliği & 138 & 20.8 \\
\hline & Sosyal Bilgiler Öğretmenliği & 131 & 19.8 \\
\hline & Okul Öncesi Öğretmenliği & 94 & 14.2 \\
\hline & Psikolojik Danışmalık ve Rehberlik Öğretmenliği & 109 & 16.5 \\
\hline & Bilgisayar ve Öğretim Teknolojileri Öğretmenliği & 63 & 9.5 \\
\hline
\end{tabular}

\section{Veri Toplama Aracı}

Bu çalışmada, öğretmen adaylarının yaşam boyu öğrenme eğilimlerini belirlemek amacıyla Diker Coşkun (2009) tarafından geliştirilen "Yaşam Boyu Öğrenme Eğilimleri Ölçeği (YBEÖ)" kullanılmıştır. Bu ölçek, likert tipi altılı dereceleme sistemine göre geliştirilmiş ve her madde için "Çok Uyuyor", "Kısmen Uyuyor", "Çok Az uyuyor", "Çok Az Uymuyor", "Kısmen Uymuyor", "Hiç Uymuyor" düzeyleri kullanılmıştır. Ölçekte toplam 27 madde yer almaktadır. Maddelerin 15'i olumsuz, 12'si olumlu yargı içermektedir. Ölçekten alınabilecek en düşük puan 27, en yüksek puan ise 162 'dir.

Yaşam boyu öğrenme eğilimi ölçeğinin, bireylerin yaşam boyu öğrenme eğilimlerini betimleyen iki olumlu ve iki olumsuz olmak üzere toplam dört alt boyutu vardır. Olumlu alt boyutlar "yaşam boyu öğrenmede motivasyon" ve "sebat" olumsuz boyutlar ise "öğrenmeyi düzenlemede yoksunluk" ve "merak yoksunluğu" boyutlarından oluşmaktadır. Yaşam boyu öğrenme ölçeğinin alt boyutları ve alt boyutlardaki madde dağılımı aşağıda verilmiştir:

1. Boyut: Motivasyon: $1,2,3,4,5,6$ bütün maddeler olumlu

2. Boyut: Sebat: 7, 8, 9, 10, 11,12 bütün maddeler olumlu

3. Boyut: Öğrenmeyi Düzenlemede Yoksunluk: 13, 14, 15, 16, 17, 18 bütün maddeler olumsuz

4. Boyut: Merak Yoksunluğu: 19, 20, 21, 22, 23, 24, 25, 26, 27 bütün maddeler olumsuz

Ölçeğin tümü için yapılan güvenirlik analizi sonucunda, Cronbach Alpha güvenirlik katsayı değeri .89 hesaplanmıştır. Bu çalışma için ölçeğin güvenirlik çalışması yeniden yapılmış Cronbach Alpha güvenirlik katsayısı .70 olarak tespit edilmiştir. Ayrıca ölçeğin araştırmada kullanımı için ölçeği geliştiren araştırmacıdan gerekli izinler alınmıştır.

Yaşam boyu öğrenme eğilimleri ölçeğinin yanı sıra öğretmen adaylarının kütüphane alışkanlıklarını belirlemek amacıyla araştırmacılar tarafından hazırlanmış bilgi formu kullanılmıştır. Bilgi formu öğretmen adaylarının kütüphane kullanım alışkanlıklarını ve demografik özelliklerini belirlemeye yönelik maddeler içermektedir.

\section{Verilerin Çözümlenmesi}

Verilerin çözümlenmesinde istatistik paket programı kullanılmıştır. Veri toplama aracından elde edilen veriler, betimsel istatistikler aracılığı ile analiz edilmiştir. Yaşam boyu öğrenme becerisi puanlarının normal dağılıma sahip olup olmadığını belirlemek için Kolmogorov-Smirnov testinden yararlanılmış ve elde edilen puanların normallik varsayımını karşılamadığı tespit edilmiştir (p<.05). Bağımlı değişken puanlarının bağımsız değişkenin her bir alt boyutunda normallik varsayımını karşılamadığı durumlarda, Mann Whitney U-testi ve Kruskal Wallis H-testi kullanılmaktadır (Büyüköztürk, Çakmak, Akgün, Karadeniz ve Demirel, 2011). Öğretmen adaylarının Yaşam Boyu Öğrenme Eğilimi Ölçeği'nden elde edilen puanların kütüphane alışkanlıklarına göre anlamlı bir farklılık gösterip göstermediğini belirlemek için ise Kruskal Wallis H-testi kullanılmıştır. Aynı zamanda Kruskal Wallis Htesti sonucunda elde edilen anlamlı farklılıkların istatistiksel açıdan hangi gruplar arasında olduğunu belirlemek amacıyla ikili gruplar arasında Mann Whitney U-testinden yararlanılmıştır.

\section{BULGULAR}

Araştırmanın birinci alt problemi "Öğretmen adaylarının kütüphaneyi kullanma sıklıklarının yaşam boyu öğrenme eğilimleri üzerinde anlamlı bir etkisi var mıdır?” şeklinde ifade edilmiştir. Öğretmen adaylarının yaşam boyu öğrenme eğilimleri ölçeğine ait alt boyut ve toplam puanlarının kütüphaneyi kullanma sıklıklarına göre istatistiksel olarak anlamlı bir farklılık gösterip göstermediğine ilişkin Kruskal Wallis H-Testi sonuçları Tablo 2'de verilmiştir. 
Tablo 2. Öğretmen adaylarının yaşam boyu öğrenme eğilimleri ölçeğine (YBÖE) ait alt boyut ve toplam puanlarının kütüphaneyi kullanma sıklıklarına göre Kruskal Wallis H-Testi sonuçları

\begin{tabular}{|c|c|c|c|c|c|c|c|}
\hline YBÖE Ölçeği Alt Boyutları & Sıklık & $\mathrm{N}$ & Sıra Ortalaması & sd & $\chi^{2}$ & $\mathrm{p}$ & $\begin{array}{c}\text { Anlamlı fark } \\
\text { (Mann Whitney) }\end{array}$ \\
\hline \multirow{6}{*}{ Motivasyon } & 1) Her gün & 46 & 286.86 & \multirow{6}{*}{5} & \multirow{6}{*}{23.966} & \multirow{6}{*}{$.000^{*}$} & \multirow{6}{*}{$\begin{array}{l}1-2,1-6 \\
2-3,3-6, \\
4-6,5-6\end{array}$} \\
\hline & 2) Haftada birkaç kez & 127 & 364.43 & & & & \\
\hline & 3) Haftada bir kez & 114 & 282.94 & & & & \\
\hline & 4) On beş günde bir & 151 & 326.06 & & & & \\
\hline & 5) Ayda bir kez & 144 & 323.52 & & & & \\
\hline & 6) Kullanmıyorum & 80 & 398.72 & & & & \\
\hline \multirow{6}{*}{ Sebat } & 1) Her gün & 46 & 283.99 & \multirow{6}{*}{5} & \multirow{6}{*}{7.433} & \multirow{6}{*}{.190} & \multirow{6}{*}{-} \\
\hline & 2) Haftada birkaç kez & 127 & 324.07 & & & & \\
\hline & 3) Haftada bir kez & 114 & 368.02 & & & & \\
\hline & 4) On beş günde bir & 151 & 332.13 & & & & \\
\hline & 5) Ayda bir kez & 144 & 328.52 & & & & \\
\hline & 6) Kullanmiyorum & 80 & 322.74 & & & & \\
\hline \multirow{6}{*}{ Öğrenmeyi Düzenleme } & 1) Her gün & 46 & 270.43 & \multirow{6}{*}{5} & \multirow{6}{*}{37.681} & \multirow{6}{*}{$.000^{*}$} & \multirow{6}{*}{$\begin{array}{c}1-2,1-5, \\
1-6,2-3, \\
2-6,3-5, \\
3-6,4-6, \\
5-6\end{array}$} \\
\hline & 2) Haftada birkaç kez & 127 & 351.44 & & & & \\
\hline & 3) Haftada bir kez & 114 & 278.71 & & & & \\
\hline & 4) On beş günde bir & 151 & 308.19 & & & & \\
\hline & 5) Ayda bir kez & 144 & 347.01 & & & & \\
\hline & 6) Kullanmıyorum & 80 & 426.26 & & & & \\
\hline \multirow{6}{*}{ Merak } & 1) Her gün & 46 & 241.39 & \multirow{6}{*}{5} & \multirow{6}{*}{20.575} & \multirow{6}{*}{$.001 *$} & \multirow{6}{*}{$\begin{array}{l}1-2,1-3 \\
1-4,1-5 \\
1-6,2-3 \\
2-4,2-5\end{array}$} \\
\hline & 2) Haftada birkaç kez & 127 & 371.72 & & & & \\
\hline & 3) Haftada bir kez & 114 & 325.39 & & & & \\
\hline & 4) On beş günde bir & 151 & 315.89 & & & & \\
\hline & 5) Ayda bir kez & 144 & 324.19 & & & & \\
\hline & 6) Kullanmıyorum & 80 & 370.79 & & & & \\
\hline \multirow{6}{*}{ Toplam } & 1) Her gün & 46 & 227.76 & \multirow{6}{*}{5} & \multirow{6}{*}{33.510} & \multirow{6}{*}{$.000^{*}$} & \multirow{6}{*}{$\begin{array}{l}1-2,1-3, \\
1-4,1-5, \\
1-6,2-3, \\
2-4,3-6, \\
4-6,5-6\end{array}$} \\
\hline & 2) Haftada birkaç kez & 127 & 361.79 & & & & \\
\hline & 3) Haftada bir kez & 114 & 306.57 & & & & \\
\hline & 4) On beş günde bir & 151 & 315.94 & & & & \\
\hline & 5) Ayda bir kez & 144 & 329.82 & & & & \\
\hline & 6) Kullanmıyorum & 80 & 410.99 & & & & \\
\hline
\end{tabular}

Tablo 2 incelendiğinde öğretmen adaylarının yaşam boyu öğrenme eğilimleri ölçeğine ait "sebat" alt boyutu hariç tüm alt boyut ve toplam puanlarının kütüphaneyi kullanma sıklıklarına göre istatistiksel olarak anlamlı bir farklılık gösterdiği belirlenmiştir. Öğretmen adaylarının "motivasyon" alt boyutuna ait puan ortalamalarının, kütüphaneyi kullanma sıklıklarına göre istatistiksel olarak anlamlı bir farklılık gösterdiği tespit edilmiştir $\left(\chi^{2}(5)=23.966 p<.05\right)$. Gruplar arasında gözlenen anlamlı farkın hangi gruplar arasında olduğunu belirlemek amacıyla grupların ikili kombinasyonları üzerinden yapılan Mann Whitney-U testi sonuçlarına göre, öğretmen adaylarının "motivasyon" alt boyutuna ait puan ortalamalarının kütüphaneyi her gün kullanan öğretmen adayları ile haftada birkaç kez kullananlar arasında haftada birkaç kez kullananlar lehine ve kütüphaneyi her gün kullanan öğretmen adayları ile kullanmayan öğretmen adayları arasında kullanmayan öğretmen adayları lehine anlamlı olarak farklılaştığı tespit edilmiştir. Kütüphaneyi haftada birkaç kez kullanan öğretmen adayları ile haftada bir kez kullanan öğretmen adayları arasında haftada birkaç kez kullanan öğretmen adayları lehine anlamlı olarak farklılaştığı tespit edilmiştir. Kütüphaneyi kullanmayan öğretmen adayları ile kütüphaneyi haftada bir kez, on beş günde bir ve ayda bir kullanan öğretmen adayları arasında kullanmayan öğretmen adayları lehine anlamlı olarak farklılaştığı bulunmuştur.

Öğretmen adaylarının “öğrenmeyi düzenleme” alt boyutuna ait puan ortalamalarının, kütüphaneyi kullanma sıklıklarına göre istatistiksel olarak anlamlı bir farklılık gösterdiği belirlenmiştir $\left(\chi^{2}(5)=37.681 p<.05\right)$. Gruplar arasında gözlenen anlamlı farkın hangi gruplar arasında olduğunu belirlemek amacıyla grupların ikili kombinasyonları üzerinden yapılan Mann Whitney-U testi sonuçlarına göre, öğretmen adaylarının "öğrenmeyi düzenleme” alt boyutuna ait puan ortalamalarının kütüphaneyi her gün kullanan öğretmen adayları ile haftada birkaç kez kullananlar arasında haftada birkaç kez kullananlar lehine ve kütüphaneyi her gün kullanan öğretmen adayları ile ayda bir kez kullanan öğretmen adayları arasında ayda bir kez kullanan öğretmen adayları 
lehine anlamlı olarak farklılaştığı tespit edilmiştir. Kütüphaneyi her gün kullananlar ile hiç kullanmayan öğretmen adayları arasında kullanmayanlar lehine istatistiksel olarak anlamlı bir farklılık olduğu tespit edilmiştir. Kütüphaneyi haftada birkaç kez kullanan öğretmen adayları ile haftada bir kez kullanan öğretmen adayları arasında haftada birkaç kez kullanan öğretmen adayları lehine anlamlı olarak farklılaştığı bulunmuştur. Kütüphaneyi kullanmayan öğretmen adayları ile kütüphaneyi haftada bir kez kullanan öğretmen adayları arasında kullanmayanlar lehine, kütüphaneyi haftada bir kez kullanan öğretmen adayları ile ayda bir kullanan öğretmen adayları arasında ayda bir kez kullananlar lehine anlamlı olarak farklılaştığı tespit edilmiştir. Kütüphaneyi kullanmayan öğretmen adayları ile kütüphaneyi haftada bir kez, on beş günde bir ve ayda bir kez kullanan öğretmen adayları arasında kullanmayanlar lehine anlamlı bir farklılık olduğu bulunmuştur.

Öğretmen adaylarının "merak" alt boyutuna ait puan ortalamalarının, kütüphaneyi kullanma sıklıklarına göre istatistiksel olarak anlamlı bir farklılık gösterdiği tespit edilmiştir $\left(\chi^{2}(5)=20.575 p<.05\right)$. Gruplar arasında gözlenen anlamlı farkın hangi gruplar arasında olduğunu belirlemek amacıyla grupların ikili kombinasyonları üzerinden yapılan Mann Whitney-U testi sonuçlarına göre, öğretmen adaylarının "merak" alt boyutuna ait puan ortalamalarının kütüphaneyi her gün kullanan öğretmen adayları ile haftada birkaç kez kullananlar arasında haftada birkaç kez kullananlar lehine ve kütüphaneyi her gün kullanan öğretmen adayları ile haftada bir kez kullanan öğretmen adayları arasında haftada bir kez kullanan öğretmen adayları lehine anlamlı olarak farklılaştığı tespit edilmiştir. Kütüphaneyi her gün kullanan öğretmen adayları ile on beş günde bir kullanan öğretmen adayları arasında on beş günde bir kullananlar lehine ve kütüphaneyi her gün kullanan öğretmen adayları ile ayda bir kez kullananlar arasında ayda bir kez kullananlar lehine anlamlı bir farklılık tespit edilmiştir. Kütüphaneyi her gün kullanan öğretmen adayları ile hiç kullanmayan öğretmen adayları arasında da hiç kullanmayanlar lehine anlamlı bir farklılık bulunmuştur. Kütüphaneyi haftada birkaç kez kullanan öğretmen adayları ile haftada bir kez kullanan öğretmen adayları, on beş günde bir kullanan öğretmen adayları ve ayda bir kez kullanan öğretmen adayları arasında haftada birkaç kez kullananlar lehine anlamlı bir farklılık bulunmuştur.

Öğretmen adaylarının yaşam boyu öğrenme eğilimi toplam puanlarının, kütüphaneyi kullanma sıklıklarına göre istatistiksel olarak anlamlı bir farklılık gösterdiği tespit edilmiştir $\left(\chi^{2}(5)=33.510 p<.05\right)$. Gruplar arasında gözlenen anlamlı farkın hangi gruplar arasında olduğunu belirlemek amacıyla grupların ikili kombinasyonları üzerinden yapılan Mann Whitney-U testi sonuçlarına göre, öğretmen adaylarının toplam puanlarının kütüphaneyi her gün kullanan öğretmen adayları ile haftada birkaç kez kullananlar arasında haftada birkaç kez kullananlar lehine ve kütüphaneyi her gün kullanan öğretmen adayları ile haftada bir kez kullanan öğretmen adayları arasında haftada bir kez kullanan öğretmen adayları lehine anlamlı olarak farklılaştığı tespit edilmiştir. Kütüphaneyi her gün kullanan öğretmen adayları ile on beş günde bir kullanan öğretmen adayları arasında on beş günde bir kullananlar lehine ve kütüphaneyi her gün kullanan öğretmen adayları ile ayda bir kez kullananlar arasında ayda bir kez kullananlar lehine anlamlı bir farklılık tespit edilmiştir. Kütüphaneyi her gün kullanan öğretmen adayları ile hiç kullanmayan öğretmen adayları arasında da hiç kullanmayanlar lehine anlamlı bir farklılık bulunmuştur. Kütüphaneyi haftada birkaç kez kullanan öğretmen adayları ile haftada bir kez kullanan öğretmen adayları ve on beş günde bir kullanan öğretmen adayları arasında haftada birkaç kez kullananlar lehine anlamlı bir farklılık bulunmuştur. Son olarak kütüphaneyi hiç kullanmayan öğretmen adayları ile haftada bir kez kullanan öğretmen adayları, on beş günde bir kullanan öğretmen adayları ve ayda bir kez kullanan öğretmen adayları arasında hiç kullanmayanlar lehine anlamlı bir farklılık tespit edilmiştir.

Araştırmanın ikinci alt problemi "Öğretmen adaylarının kütüphaneyi kullanma amaçlarının yaşam boyu öğrenme eğilimleri üzerinde anlamlı bir etkisi var mıdır?” şeklinde ifade edilmiştir. Öğretmen adaylarının yaşam boyu öğrenme eğilimleri ölçeğine ait alt boyut ve toplam puanlarının kütüphaneyi kullanma amaçlarına göre istatistiksel olarak anlamlı bir farklılık gösterip göstermediğine ilişkin Kruskal Wallis H-Testi sonuçları Tablo 3' te verilmiştir.

Tablo 3. Öğretmen adaylarının yaşam boyu öğrenme eğilimleri ölçeğine (YBÖE) ait alt boyut ve toplam puanlarının kütüphaneyi kullanma amaçlarına göre Kruskal Wallis H-Testi sonuçları

\begin{tabular}{|c|c|c|c|c|c|c|c|}
\hline YBÖE Ölçeği Alt Boyutları & Amaç & $\mathrm{N}$ & $\begin{array}{c}\text { Sıra } \\
\text { Ortalaması }\end{array}$ & sd & $\chi^{2}$ & $\mathrm{p}$ & $\begin{array}{c}\text { Anlamlı fark } \\
\text { (Mann } \\
\text { Whitney) }\end{array}$ \\
\hline \multirow{6}{*}{ Motivasyon } & 1) Ders çalışmak için & 212 & 362.09 & \multirow{6}{*}{5} & \multirow{6}{*}{37.314} & \multirow{6}{*}{$.000^{*}$} & \multirow{6}{*}{$\begin{array}{l}1-2,1-3 \\
1-5,1-6 \\
2-6,3-6 \\
4-6,5-6\end{array}$} \\
\hline & 2) Ödevlerimi yapmak için & 104 & 308.18 & & & & \\
\hline & $\begin{array}{l}\text { 3) Roman hikaye okumak } \\
\text { için }\end{array}$ & 110 & 291.92 & & & & \\
\hline & 4) Ödünç kitap almak için & 104 & 319.99 & & & & \\
\hline & 5) Araştırma yapmak için & 105 & 300.90 & & & & \\
\hline & 6) Internet için & 27 & 505.80 & & & & \\
\hline \multirow{6}{*}{ Sebat } & 1) Ders çalışmak için & 212 & 314.71 & \multirow{6}{*}{5} & \multirow{6}{*}{4.926} & \multirow{6}{*}{.425} & \multirow{6}{*}{-} \\
\hline & 2) Ödevlerimi yapmak için & 104 & 330.59 & & & & \\
\hline & $\begin{array}{l}\text { 3) Roman hikaye okumak } \\
\text { için }\end{array}$ & 110 & 342.27 & & & & \\
\hline & 4) Ödünç kitap almak için & 104 & 350.06 & & & & \\
\hline & 5) Araştırma yapmak için & 105 & 324.03 & & & & \\
\hline & 6) Internet için & 27 & 380.52 & & & & \\
\hline
\end{tabular}

| Kastamonu Eğitim Dergisi, 2020, Vol. 28, No. 3| 


\begin{tabular}{|c|c|c|c|c|c|c|c|}
\hline YBÖE Ölçeği Alt Boyutları & Amaç & $\mathrm{N}$ & $\begin{array}{c}\text { Sıra } \\
\text { Ortalaması }\end{array}$ & sd & $\chi^{2}$ & $\mathrm{p}$ & $\begin{array}{c}\text { Anlamlı fark } \\
\text { (Mann } \\
\text { Whitney) }\end{array}$ \\
\hline \multirow{6}{*}{ Öğrenmeyi Düzenleme } & 1) Ders çalışmak için & 212 & 351.97 & \multirow{6}{*}{5} & \multirow{6}{*}{11.176} & \multirow{6}{*}{$.048^{*}$} & \multirow{6}{*}{$\begin{array}{l}1-2,1-4 \\
2-6,3-6 \\
4-6,5-6\end{array}$} \\
\hline & 2) Ödevlerimi yapmak için & 104 & 305.26 & & & & \\
\hline & $\begin{array}{l}\text { 3) Roman hikaye okumak } \\
\text { için }\end{array}$ & 110 & 327.60 & & & & \\
\hline & 4) Ödünç kitap almak için & 104 & 304.71 & & & & \\
\hline & 5) Araştırma yapmak için & 105 & 326.47 & & & & \\
\hline & 6) İnternet için & 27 & 410.46 & & & & \\
\hline \multirow{6}{*}{ Merak } & 1) Ders çalışmak için & 212 & 348.23 & \multirow{6}{*}{5} & \multirow{6}{*}{7.438} & \multirow{6}{*}{.190} & \multirow{6}{*}{-} \\
\hline & 2) Ödevlerimi yapmak için & 104 & 302.46 & & & & \\
\hline & $\begin{array}{l}\text { 3) Roman hikaye okumak } \\
\text { için }\end{array}$ & 110 & 332.92 & & & & \\
\hline & 4) Ödünç kitap almak için & 104 & 303.96 & & & & \\
\hline & 5) Araştırma yapmak için & 105 & 343.76 & & & & \\
\hline & 6) İnternet için & 27 & 364.59 & & & & \\
\hline \multirow{6}{*}{ Toplam } & 1) Ders çalışmak için & 212 & 351.67 & \multirow{6}{*}{5} & \multirow{6}{*}{19.793} & \multirow{6}{*}{$.001^{*}$} & \multirow{6}{*}{$\begin{array}{l}1-2,1-6, \\
2-6,3-6 \\
4-6,5-6\end{array}$} \\
\hline & 2) Ödevlerimi yapmak için & 104 & 298.79 & & & & \\
\hline & $\begin{array}{l}\text { 3) Roman hikaye okumak } \\
\text { için }\end{array}$ & 110 & 320.94 & & & & \\
\hline & 4) Ödünç kitap almak için & 104 & 313.41 & & & & \\
\hline & 5) Araştırma yapmak için & 105 & 318.52 & & & & \\
\hline & 6) İnternet için & 27 & 462.31 & & & & \\
\hline
\end{tabular}

Tablo 3 incelendiğinde öğretmen adaylarının yaşam boyu öğrenme eğilimleri ölçeğine ait "sebat" ve "merak" alt boyutları hariç tüm alt boyut ve toplam puanlarının kütüphaneyi kullanma amaçlarına göre istatistiksel olarak anlamlı bir farklılık gösterdiği belirlenmiştir.

Öğretmen adaylarının "motivasyon" alt boyutuna ait puan ortalamalarının, kütüphaneyi kullanma amaçlarına göre istatistiksel olarak anlamlı bir farklılık gösterdiği tespit edilmiştir $\left(\chi^{2}(5)=37.314 p<.05\right)$. Gruplar arasında gözlenen anlamlı farkın hangi gruplar arasında olduğunu belirlemek amacıyla grupların ikili kombinasyonları üzerinden yapılan Mann Whitney-U testi sonuçlarına göre, öğretmen adaylarının "motivasyon” alt boyutuna ait puan ortalamalarının kütüphaneyi ders çalışma amacıyla kullanan öğretmen adayları ile ödev yapmak amacıyla kullananlar, roman hikaye okumak için kullananlar ve araştırma yapmak için kullananlar arasında ders çalışmak için kullananlar lehine anlamlı bir farklılık tespit edilmiştir. Kütüphaneyi ders çalışmak için kullanan öğretmen adayları ile internet için kullanan öğretmen adayları arasında ise internet için kullananlar lehine anlamlı bir farklılık bulunmuştur. Kütüphaneyi internet için kullanan öğretmen adayları ile ödevlerini yapmak için kullananlar, roman, hikaye okumak için kullananlar, ödünç kitap almak için kullananlar ve araştırma yapmak için kullananlar arasında internet için kullananlar lehine anlamlı bir farklılık tespit edilmiştir.

Öğretmen adaylarının yaşam boyu öğrenme eğilimleri ölçeği “öğrenmeyi düzenleme” alt boyutuna ait puan ortalamalarının, kütüphaneyi kullanma amaçlarına göre istatistiksel olarak anlamlı bir farklılık gösterdiği tespit edilmiştir $\left(\chi^{2}(5)=11.176 p<.05\right)$. Gruplar arasında gözlenen anlamlı farkın hangi gruplar arasında olduğunu belirlemek amacıyla grupların ikili kombinasyonları üzerinden yapılan Mann Whitney-U testi sonuçlarına göre, öğretmen adaylarının "öğrenmeyi düzenleme" alt boyutuna ait puan ortalamalarının kütüphaneyi ders çalışma amacıyla kullanan öğretmen adayları ile ödev yapmak amacıyla kullananlar ve ödünç kitap almak için kullananlar arasında ders çalışmak için kullananlar lehine anlamlı bir farklılık tespit edilmiştir. Kütüphaneyi internet için kullanan öğretmen adayları ile ödevlerini yapmak için kullananlar, roman, hikaye okumak için kullananlar, ödünç kitap almak için kullananlar ve araştırma yapmak için kullananlar arasında internet için kullananlar lehine anlamlı bir farklılık tespit edilmiştir.

Öğretmen adaylarının yaşam boyu öğrenme eğilimleri ölçeği toplam puanlarının, kütüphaneyi kullanma amaçlarına göre istatistiksel olarak anlamlı bir farklılık gösterdiği tespit edilmiştir $\left(\chi^{2}(5)=19.793 p<.05\right)$. Gruplar arasında gözlenen anlamlı farkın hangi gruplar arasında olduğunu belirlemek amacıyla grupların ikili kombinasyonları üzerinden yapılan Mann Whitney-U testi sonuçlarına göre, öğretmen adaylarının toplam puanlarının kütüphaneyi ders çalışma amacıyla kullanan öğretmen adayları ile ödev yapmak amacıyla kullananlar arasında ders çalışma amacıyla kullananlar lehine ve kütüphaneyi ders çalışma amacıyla kullanan öğretmen adayları ile internet için kullanan öğretmen adayları arasında internet için kullanan lehine anlamlı bir farklılık tespit edilmiştir. Kütüphaneyi internet için kullanan öğretmen adayları ile ödevlerini yapmak için kullananlar, roman, hikaye okumak için kullananlar, ödünç kitap almak için kullananlar ve araştırma yapmak için kullananlar arasında internet için kullananlar lehine anlamlı bir farklılık tespit edilmiştir.

Araştırmanın üçüncü alt problemi “Öğretmen adaylarının kitap okuma sıklıklarının yaşam boyu öğrenme eğilimleri üzerinde anlamlı bir etkisi var mıdır?” şeklinde ifade edilmiştir. Öğretmen adaylarının yaşam boyu öğrenme becerileri ölçeğine ait alt boyut 
ve toplam puanlarının kitap okuma sıklıklarına göre istatistiksel olarak anlamlı bir farklılık gösterip göstermediğine ilişkin Kruskal Wallis H-Testi sonuçları Tablo 4'te verilmiştir.

Tablo 4. Öğretmen adaylarının yaşam boyu öğrenme eğilimleri ölçeğine (YBÖE) ait alt boyut ve toplam puanlarının kitap okuma sıklıklarına göre Kruskal Wallis H-Testi sonuçları

\begin{tabular}{|c|c|c|c|c|c|c|c|}
\hline $\begin{array}{l}\text { YBÖE Ölçeği Alt } \\
\text { Boyutları }\end{array}$ & Sıklık & $\mathrm{N}$ & Sıra Ortalaması & sd & $\chi^{2}$ & $\mathrm{p}$ & $\begin{array}{c}\text { Anlamlı fark } \\
\text { (Mann } \\
\text { Whitney) }\end{array}$ \\
\hline \multirow{4}{*}{ Motivasyon } & $\begin{array}{l}\text { 1) Yılda } 15 \text { kitap ve } \\
\text { üstü }\end{array}$ & 116 & 355.63 & \multirow{4}{*}{3} & \multirow{4}{*}{10.787} & \multirow{4}{*}{$.013 *$} & \multirow{4}{*}{$\begin{array}{c}\text { 1-4, 2-4, } \\
3-4\end{array}$} \\
\hline & 2) Yılda 6-14 kitap & 195 & 341.01 & & & & \\
\hline & 3) Yılda 1-5 kitap & 275 & 332.16 & & & & \\
\hline & 4) Hiç okumam & 76 & 267.87 & & & & \\
\hline \multirow{4}{*}{ Sebat } & $\begin{array}{l}\text { 1) Yılda } 15 \text { kitap ve } \\
\text { üstü }\end{array}$ & 116 & 331.50 & \multirow{4}{*}{3} & \multirow{4}{*}{3.350} & \multirow{4}{*}{.341} & \multirow{4}{*}{-} \\
\hline & 2) Yılda 6-14 kitap & 195 & 313.82 & & & & \\
\hline & 3) Yılda 1-5 kitap & 275 & 345.93 & & & & \\
\hline & 4) Hiç okumam & 76 & 324.64 & & & & \\
\hline \multirow{4}{*}{$\begin{array}{l}\text { Öğrenmeyi } \\
\text { Düzenleme }\end{array}$} & $\begin{array}{l}\text { 1) Yılda } 15 \text { kitap ve } \\
\text { üstü }\end{array}$ & 116 & 326.70 & \multirow{4}{*}{3} & \multirow{4}{*}{2.936} & \multirow{4}{*}{.402} & \multirow{4}{*}{-} \\
\hline & 2) Yılda 6-14 kitap & 195 & 328.15 & & & & \\
\hline & 3) Yılda 1-5 kitap & 275 & 343.74 & & & & \\
\hline & 4) Hiç okumam & 76 & 303.15 & & & & \\
\hline \multirow{4}{*}{ Merak } & $\begin{array}{l}\text { 1) Yılda } 15 \text { kitap ve } \\
\text { üstü }\end{array}$ & 116 & 315.27 & \multirow{4}{*}{3} & \multirow{4}{*}{2.159} & \multirow{4}{*}{.540} & \multirow{4}{*}{-} \\
\hline & 2) Yılda 6-14 kitap & 195 & 324.52 & & & & \\
\hline & 3) Yılda 1-5 kitap & 275 & 343.37 & & & & \\
\hline & 4) Hiç okumam & 76 & 331.22 & & & & \\
\hline \multirow{4}{*}{ Toplam } & $\begin{array}{l}\text { 1) Yılda } 15 \text { kitap ve } \\
\text { üstü }\end{array}$ & 116 & 336.78 & \multirow{4}{*}{3} & \multirow{4}{*}{4.683} & \multirow{4}{*}{.197} & \multirow{4}{*}{-} \\
\hline & 2) Yılda 6-14 kitap & 195 & 323.86 & & & & \\
\hline & 3) Yılda 1-5 kitap & 275 & 345.02 & & & & \\
\hline & 4) Hiç okumam & 76 & 294.11 & & & & \\
\hline
\end{tabular}

Tablo 4 incelendiğinde öğretmen adaylarının yaşam boyu öğrenme eğilimleri ölçeğine ait puan ortalamalarının "motivasyon" alt boyutu hariç tüm alt boyut ve toplam puanlarının kitap okuma sıklıklarına göre istatistiksel olarak anlamlı bir farklılık gösterdiği belirlenmiştir.

Öğretmen adaylarının "motivasyon" alt boyutuna ait puan ortalamalarının, kitap okuma sıklıklarına göre istatistiksel olarak anlamlı bir farklılık gösterdiği tespit edilmiştir $\left(\chi^{2}(5)=10.787 p<.05\right)$. Gruplar arasında gözlenen anlamlı farkın hangi gruplar arasında olduğunu belirlemek amacıyla grupların ikili kombinasyonları üzerinden yapılan Mann Whitney-U testi sonuçlarına göre, öğretmen adaylarının "motivasyon" alt boyutuna ait puan ortalamalarının yılda on beş kitap ve üstü okuyan öğretmen adayları ile hiç okumayanlar arasında yılda on beş kitap ve üstü okuyanlar lehine, yılda 6-14 kitap okuyanlar ile hiç okumayanlar arasında yılda 614 kitap okuyanlar lehine ve yılda 1-5 kitap okuyanlar ile hiç okumayanlar arasında yılda 1-5 kitap okuyanlar lehine anlamlı bir farklılık tespit edilmiştir.

Araştırmanın dördüncü alt problemi "Öğretmen adaylarının kitap okumasını engelleyen faktörlerin yaşam boyu öğrenme eğilimleri üzerinde anlamlı bir etkisi var mıdır?” şeklinde ifade edilmiştir. Öğretmen adaylarının yaşam boyu öğrenme eğilimleri ölçeğine ait alt boyut ve toplam puanlarının kitap okumayı etkileyen faktörlere göre istatistiksel olarak anlamlı bir farklılık gösterip göstermediğine ilişkin Kruskal Wallis $\mathrm{H}$-Testi sonuçları Tablo 5'te verilmiştir. 
Tablo 5. Öğretmen adaylarının yaşam boyu öğrenme eğilimleri ölçeğine (YBÖE) ait alt boyut ve toplam puanlarının kitap okumayı etkileyen faktörlere göre Kruskal Wallis H-Testi sonuçları

\begin{tabular}{|c|c|c|c|c|c|c|c|}
\hline $\begin{array}{l}\text { YBÖE Ölçeği Alt } \\
\text { Boyutları }\end{array}$ & $\begin{array}{l}\text { Kitap okumayı engelleyen } \\
\text { faktörler }\end{array}$ & N & Sıra Ortalaması & sd & $\chi^{2}$ & $\mathrm{p}$ & $\begin{array}{c}\text { Anlamlı fark } \\
\text { (Mann } \\
\text { Whitney) }\end{array}$ \\
\hline \multirow{7}{*}{ Motivasyon } & 1) Derslerin yoğunluğu & 162 & 357.48 & \multirow{7}{*}{6} & \multirow{7}{*}{67.134} & \multirow{7}{*}{$.000^{*}$} & \multirow{7}{*}{$\begin{array}{l}\text { 1-3, 1-4, } \\
\text { 1-5, 1-6, } \\
\text { 1-7, 2-3, } \\
2-4,2-5, \\
2-6,2-7 \\
3-6,3-7, \\
4-6,4-7 \\
5-6,5-7\end{array}$} \\
\hline & $\begin{array}{l}\text { 2) Okuma alışkanlığımın } \\
\text { olmaması }\end{array}$ & 115 & 360.36 & & & & \\
\hline & $\begin{array}{l}\text { 3) Bilgisayar ve internet } \\
\text { kullanmak }\end{array}$ & 127 & 283.96 & & & & \\
\hline & 4) Televizyon izlemek & 86 & 238.48 & & & & \\
\hline & $\begin{array}{l}\text { 5) Kitap fiyatlarının yüksek } \\
\text { olması }\end{array}$ & 84 & 292.76 & & & & \\
\hline & 6) Zaman bulamıyorum & 62 & 443.90 & & & & \\
\hline & 7) İlgimi çekmiyor & 26 & 438.98 & & & & \\
\hline \multirow{7}{*}{ Sebat } & 1) Derslerin yoğunluğu & 162 & 320.86 & \multirow{7}{*}{6} & \multirow{7}{*}{2.129} & \multirow{7}{*}{.907} & \multirow{7}{*}{-} \\
\hline & $\begin{array}{l}\text { 2) Okuma alışkanlığımın } \\
\text { olmaması }\end{array}$ & 115 & 344.67 & & & & \\
\hline & $\begin{array}{l}\text { 3) Bilgisayar ve internet } \\
\text { kullanmak }\end{array}$ & 127 & 326.08 & & & & \\
\hline & 4) Televizyon izlemek & 86 & 339.67 & & & & \\
\hline & $\begin{array}{l}\text { 5) Kitap fiyatlarının yüksek } \\
\text { olması }\end{array}$ & 84 & 340.13 & & & & \\
\hline & 6) Zaman bulamıyorum & 62 & 315.66 & & & & \\
\hline & 7) ilgimi çekmiyor & 26 & 348.90 & & & & \\
\hline \multirow{7}{*}{ Öğrenmeyi Düzenleme } & 1) Derslerin yoğunluğu & 162 & 352.85 & \multirow{7}{*}{6} & \multirow{7}{*}{41.858} & \multirow{7}{*}{$.000^{*}$} & \multirow{7}{*}{$\begin{array}{c}1-3,1-4,1-6,2- \\
4,2-6,2-7,3-4,3- \\
6,3-7,4-5,4-6,4- \\
7,5-6,5-7\end{array}$} \\
\hline & $\begin{array}{l}\text { 2) Okuma alışkanlığımın } \\
\text { olmaması }\end{array}$ & 115 & 330.77 & & & & \\
\hline & $\begin{array}{l}\text { 3) Bilgisayar ve internet } \\
\text { kullanmak }\end{array}$ & 127 & 304.33 & & & & \\
\hline & 4) Televizyon izlemek & 86 & 248.63 & & & & \\
\hline & $\begin{array}{l}\text { 5) Kitap fiyatlarının yüksek } \\
\text { olması }\end{array}$ & 84 & 320.10 & & & & \\
\hline & 6) Zaman bulamıyorum & 62 & 426.62 & & & & \\
\hline & 7) ilgimi çekmiyor & 26 & 418.56 & & & & \\
\hline \multirow{7}{*}{ Merak } & 1) Derslerin yoğunluğu & 162 & 364.88 & \multirow{7}{*}{6} & \multirow{7}{*}{14.346} & \multirow{7}{*}{$.000 *$} & \multirow{7}{*}{ 1-3,3-4,3-5, } \\
\hline & $\begin{array}{l}\text { 2) Okuma alışkanlığımın } \\
\text { olmaması }\end{array}$ & 115 & 315.37 & & & & \\
\hline & $\begin{array}{l}\text { 3) Bilgisayar ve internet } \\
\text { kullanmak }\end{array}$ & 127 & 285.42 & & & & \\
\hline & 4) Televizyon izlemek & 86 & 333.67 & & & & \\
\hline & $\begin{array}{l}\text { 5) Kitap fiyatlarının yüksek } \\
\text { olması }\end{array}$ & 84 & 345.06 & & & & \\
\hline & 6) Zaman bulamıyorum & 62 & 333.56 & & & & \\
\hline & 7) Ilgimi çekmiyor & 26 & 364.04 & & & & \\
\hline \multirow{7}{*}{ Toplam } & 1) Derslerin yoğunluğu & 162 & 362.74 & \multirow{7}{*}{6} & \multirow{7}{*}{37.331} & \multirow{7}{*}{$.000 *$} & \multirow{7}{*}{$\begin{array}{c}1-3,1-4,2-6,3- \\
6,3-7,4-6,4-7,5- \\
6,5-7\end{array}$} \\
\hline & $\begin{array}{l}\text { 2) Okuma alışkanlığımın } \\
\text { olmaması }\end{array}$ & 115 & 331.57 & & & & \\
\hline & $\begin{array}{l}\text { 3) Bilgisayar ve internet } \\
\text { kullanmak }\end{array}$ & 127 & 280.19 & & & & \\
\hline & 4) Televizyon izlemek & 86 & 273.78 & & & & \\
\hline & $\begin{array}{l}\text { 5) Kitap fiyatlarının yüksek } \\
\text { olması }\end{array}$ & 84 & 322.82 & & & & \\
\hline & 6) Zaman bulamıyorum & 62 & 411.88 & & & & \\
\hline & 7) İlgimi çekmiyor & 26 & 414.42 & & & & \\
\hline
\end{tabular}

Tablo 5 incelendiğinde öğretmen adaylarının yaşam boyu öğrenme eğilimleri ölçeğine ait "sebat" alt boyutu hariç tüm alt boyut ve toplam puanlarının kitap okumasını engelleyen faktörlere göre istatistiksel olarak anlamlı bir farklılık gösterdiği belirlenmiştir. 
Öğretmen adaylarının Yaşam Boyu Öğrenme Eğilimleri Ölçeği “motivasyon” alt boyutuna ait puan ortalamalarının, kitap okumasını engelleyen faktörlere göre istatistiksel olarak anlamlı bir farklılık gösterdiği tespit edilmiştir $\left(\chi^{2}(5)=67.134\right.$ p<.05). Gruplar arasında gözlenen anlamlı farkın hangi gruplar arasında olduğunu belirlemek amacıyla grupların ikili kombinasyonları üzerinden yapılan Mann Whitney-U testi sonuçlarına göre, öğretmen adaylarının “motivasyon” alt boyutuna ait puan ortalamalarının kitap okumayı engelleyen faktörlerden derslerin yoğunluğunu seçen öğretmen adayları ile bilgisayar ve internet kullanmak, televizyon izlemek ve kitap fiyatlarının yüksek olmasını seçen öğretmen adayları arasında derslerin yoğunluğu lehine anlamalı bir farklılık tespit edilmiştir. Kitap okumayı engelleyen faktörlerden derslerin yoğunluğunu seçen öğretmen adayları ile zaman bulamıyorum ifadesini seçen öğretmen adayları arasında zaman bulamıyorum seçenler lehine ve derslerin yoğunluğunu seçen öğretmen adayları ile ilgimi çekmiyorum ifadesini seçenler arasında da ilgimi çekmiyor seçenler lehine anlamlı farklılıklar tespit edilmiştir. Kitap okumayı engelleyen faktörlerden okuma alışkanlığımın olmaması ifadesini seçen öğretmen adayları ile bilgisayar ve internet kullanmak, televizyon izlemek ve kitap fiyatlarının yüksek olmasını seçen öğretmen adayları arasında okuma alışkanlığımın olmaması ifadesini lehine anlamlı bir farklııı tespit edilmiştir. Kitap okumayı engelleyen faktörlerden okuma alışkanlığımın olmaması ifadesini seçen öğretmen adayları ile zaman bulamıyorum ifadesini seçen öğretmen adayları arasında zaman bulamıyorum seçenler lehine ve okuma alışkanlığımın olmaması ifadesini seçen öğretmen adayları ile ilgimi çekmiyorum ifadesini seçenler arasında da ilgimi çekmiyor seçenler lehine anlamlı farklılıklar bulunmuştur. Kitap okumayı engelleyen faktörlerden bilgisayar ve internet kullanmak ifadesini tercih eden öğretmen adayları ile zaman bulamıyorum ifadesini seçenler arasında zaman bulamayanlar lehine anlamlı farklılıklar olduğu tespit edilmiştir. Bilgisayar ve internet kullanmak ifadesini tercih eden öğretmen adayları ile ilgimi çekmiyor ifadesini seçenler arasında ilgimi çekmiyor ifadesini tercih edenler lehine anlamlı farklılıklar olduğu tespit edilmiştir. Kitap okumayı engelleyen faktörlerden televizyon izlemek ifadesini tercih eden öğretmen adayları ile zaman bulamıyorum ifadesini seçenler arasında zaman bulamayanlar lehine anlamlı farklılıklar olduğu bulunmuştur. Televizyon izlemek ifadesini tercih eden öğretmen adayları ile ilgimi çekmiyor ifadesini seçenler arasında ilgimi çekmiyor ifadesini tercih edenler lehine anlamlı farklılıklar olduğu tespit edilmiştir. Kitap okumayı engelleyen faktörlerden kitap fiyatlarının yüksek olması ifadesini tercih eden öğretmen adayları ile zaman bulamıyorum ifadesini seçenler arasında zaman bulamayanlar lehine anlamlı farklılıklar olduğu bulunmuştur. Kitap fiyatlarının yüksek olması ifadesini tercih eden öğretmen adayları ile ilgimi çekmiyor ifadesini seçenler arasında ilgimi çekmiyor ifadesini tercih edenler lehine anlamlı farklılıklar olduğu tespit edilmiştir.

Öğretmen adaylarının yaşam boyu öğrenme eğilimleri ölçeği "öğrenmeyi düzenleme” alt boyutuna ait puan ortalamalarının, kitap okumasını engelleyen faktörlere göre istatistiksel olarak anlamlı bir farklılık gösterdiği tespit edilmiştir $\left(\chi^{2}(5)=41.858 p<.05\right)$. Gruplar arasında gözlenen anlamlı farkın hangi gruplar arasında olduğunu belirlemek amacıyla grupların ikili kombinasyonları üzerinden yapılan Mann Whitney-U testi sonuçlarına göre, öğretmen adaylarının "öğrenmeyi düzenleme" alt boyutuna ait puan ortalamalarının kitap okumayı engelleyen faktörlerden derslerin yoğunluğunu seçen öğretmen adayları ile bilgisayar ve internet kullanmak, televizyon izlemek ifadelerini seçen öğretmen adayları arasında derslerin yoğunluğu lehine anlamlı bir farklılık tespit edilmiştir. Aynı şekilde derslerin yoğunluğunu seçen öğretmen adayları ile zaman bulamıyorum ifadesini seçen öğretmen adayları arasında zaman bulamıyorum seçenler lehine anlamlı bir farklılık bulunmuştur. Kitap okumayı engelleyen faktörlerden okuma alışkanlığının olmaması ifadesini tercih eden öğretmen adayları ile televizyon izlemeyi seçenler arasında okuma alışkanlığının olmayanlar lehine anlamlı farklılıklar bulunmuştur. Okuma alışkanlığı olmayan öğretmen adayları ile zaman bulamayan öğretmen adayları arasında zaman bulamayanlar lehine ve okuma alışkanlığı olmayan öğretmen adayları ile ilgimi çekmiyor ifadesini seçen öğretmen adayları arasında ilgimi çekmiyor seçenler lehine anlamlı farklılıklar belirlenmiştir. Bilgisayar ve internet kullanmayı engel olarak gören öğretmen adayları ile televizyon izleyenler arasında bilgisayar ve internet kullananlar lehine anlamlı farklılıklar tespit edilmiştir. Bilgisayar ve internet kullanmayı engel olarak gören öğretmen adayları ile zaman bulamayan öğretmen adayları arasında zaman bulamayanlar lehine ve bilgisayar ve internet kullanan öğretmen adayları ile ilgimi çekmiyor ifadesini seçen öğretmen adayları arasında ilgimi çekmiyor ifadesini seçenler arasında anlamlı farklılıklar bulunmuştur. Televizyon izlemeyi engel olarak gören öğretmen adayları ile kitap fiyatlarının yüksek olması seçen öğretmen adayları arasında kitap fiyatlarını yüksek bulanlar lehine ve televizyon izleyenler ile zaman bulamayan öğretmen adayları arasında zaman bulamayanlar lehine anlamlı farklılıklar tespit edilmiştir. Kitap okumanın ilgilerini çekmediğini ifade eden öğretmen adaylarının yaşam boyu öğrenme eğilimi öğrenmeyi düzenleme alt boyut puanları televizyon izlediğini ve kitap fiyatlarının yüksek olduğunu ifade eden öğretmen adaylarından daha yüksek bulunmuştur. Kitap okumak için zaman bulamadığını ifade eden öğretmen adaylarının yaşam boyu öğrenme eğilimi öğrenmeyi düzenleme alt boyut puanları kitap fiyatlarının yüksek olmasını tercih edenlere göre daha yüksek olduğu görülmüştür.

Öğretmen adaylarının Yaşam Boyu Öğrenme Eğilimleri Ölçeği “merak” alt boyut puan ortalamalarının, kitap okumayı engelleyen faktörlere göre istatistiksel olarak anlamlı bir farklılık gösterdiği tespit edilmiştir $\left(\chi^{2}(5)=14.346 p<.05\right)$. Gruplar arasında gözlenen anlamlı farkın hangi gruplar arasında olduğunu belirlemek amacıyla grupların ikili kombinasyonları üzerinden yapılan Mann Whitney-U testi sonuçları incelenmiştir. Buna göre derslerin yoğunluğundan, televizyon izlemekten ve kitap fiyatlarının yüksek olmasından dolayı kitap okumadığını ifade eden öğretmen adaylarının yaşam boyu öğrenmeye yönelik merak puanları bilgisayar ve internet kullanmayı tercih edenlere göre daha yüksek bulunmuştur.

Öğretmen adaylarının Yaşam Boyu Öğrenme Eğilimleri Ölçeği toplam puanlarının, kitap okumayı engelleyen faktörlere göre istatistiksel olarak anlamlı bir farklılık gösterdiği tespit edilmiştir $\left(\chi^{2}(5)=37.331 p<.05\right)$. Gruplar arasında gözlenen anlamlı farkın hangi gruplar arasında olduğunu belirlemek amacıyla grupların ikili kombinasyonları üzerinden yapılan Mann Whitney-U testi sonuçları doğrultusunda, derslerin yoğunluğundan dolayı kitap okumadığını belirten öğretmen adaylarının, televizyon izleyen, bilgisayar kullanan ve internette vakit geçiren öğretmen adaylarına göre yaşam boyu öğrenme eğilimlerinin daha yüksek olduğu bulunmuştur. Kitap okumaya zamanı olmayan öğretmen adaylarının yaşam boyu öğrenme eğilimleri okuma alışkanlığı olmayanlara

| Kastamonu Eğitim Dergisi, 2020, Vol. 28, No. 3| 
göre daha yüksek tespit edilmiştir. Zaman bulamadığı için ve ilgisini çekmediği için kitap okumayan öğretmen adaylarının yaşam boyu öğrenme eğilimleri bilgisayar ve internet kullananlara göre daha yüksektir. Zaman bulamadığı için ve ilgisini çekmediği için kitap okumayan öğretmen adaylarının yaşam boyu öğrenme eğilimleri televizyon izleyen öğretmen adaylarından daha yüksek bulunmuştur. Elde edilen veriler incelendiğinde, kitap okumaya zaman bulamayan ve kitap okumak ilgisini çekmeyen öğretmen adaylarının yaşam boyu öğrenme eğilimleri kitap fiyatları yüksek olduğu için okumayanlara göre daha yüksek olduğu söylenebilir.

\section{TARTIŞMA VE SONUÇ}

Araştırma sonucunda, öğretmen adaylarının Yaşam Boyu Öğrenme Eğilimleri Ölçeği “motivasyon”, “öğrenmeyi düzenlenme”, "merak" alt boyut puanları ve toplam puanlarının, kütüphaneyi kullanma sıklıklarına göre istatistiksel olarak anlamlı bir farklılık gösterdiği tespit edilmiştir. Elde edilen bu farklılık incelendiğinde, öğretmen adaylarının kütüphaneyi sıklıkla kullanmalarının onların yaşam boyu öğrenme eğilimlerini genel olarak olumlu etkilediği ancak olumsuz etkisinin de bulunduğu görülmektedir. Bu durumun nedenlerinden biri olarak, bireylere küçük yaşlarda kütüphane kullanma alışkanlığının kazandırılamaması gösterilebilir. Kütüphane kullanımını alışkanlık haline getirmeyen bireyler günlük hayatlarında var olan bilgileri sadece yaşantılarından ve tecrübelerinden edindiklerini düşünmektedirler. Bu sonucun ortaya çıkmasında etkili olan bir diğer etken ise son yıllarda eğitim sistemimizde teknolojik faaliyetlerin ön plana çıkması olarak gösterilebilir. Aynı zamanda çalışmada, haftada birkaç kez kütüphaneye giden öğretmen adaylarının, kütüphaneye ayda bir kez giden öğretmen adaylarına göre anlamlı derecede daha yüksek yaşam boyu öğrenme eğilimine sahip oldukları sonucuna ulaşılmıştır. Okuma alışkanlığı bireylerin okuma eylemini düzenli ve sürekli bir şekilde yapması olarak tanımlanırken, kütüphane kullanma alışkanlığı ise belli aralıklarla ve çeşitli nedenlerle kütüphanelerden yararlanma olarak tanımlanabilmektedir.

Kütüphane kullanma alışkanlığı bireylerin düşünme şekillerine, kişiliklerine ve yaşam boyu öğrenmelerine olumlu katkıda bulunmaktadır (Yılmaz, 2002). Bu sebeple haftada birkaç kez kütüphaneye giden öğretmen adaylarının, kütüphaneye ayda bir kez giden öğretmen adaylarına göre anlamlı derecede daha yüksek yaşam boyu öğrenme eğilimine sahip olmaları bu sonucu doğrular niteliktedir. Alanyazın incelendiğinde bu sonucu destekler nitelikte çalışmalara rastlanılamamıştır. Ancak kütüphaneye gitme sıklı̆̆ını inceleyen çalışmalara rastlanılmıştır. Bu doğrultuda Odabaş, Odabaş ve Polat (2008) çalışmalarındada üniversite öğrencilerinin \% 63.8 oranında büyük bir kısmının kütüphaneye nadiren gittiğini, \% 15.5'inin her hafta, \%15,8'inin ise her ay, \% 3.3'ünün her gün gittiğini tespit etmişlerdir.. Benzer şekilde Yılmaz (2004) yapmış olduğu çalışmada öğrencilerin \%50,6'sının kütüphaneye hiç gitmediklerini, \%13.7'sinin ayda bir kütüphaneye gittiğini tespit etmiştir.

Araştırmada öğretmen adaylarının Yaşam Boyu Öğrenme Eğilimleri Ölçeğine ait "sebat" ve "merak" alt boyutları hariç tüm alt boyut ve toplam puanlarının kütüphaneyi kullanma amaçlarına göre istatistiksel olarak anlamlı bir farklılık gösterdiği belirlenmiştir. Sonuç olarak; kütüphaneyi internet için kullanan öğretmen adaylarının Yaşam Boyu Öğrenme Eğilimleri Ölçeği "motivasyon” alt boyutu, "öğrenmeyi düzenleme" alt boyutu ve toplam puanlarının daha yüksek olduğu tespit edilmiştir. Bu durumun nedeni olarak yaşadığımız dönemde gerçekleşen teknolojik gelişmeler ilk sırada gösterilebilir. Günümüzde hızla gelişen teknoloji toplumdaki bireylerin özelliklerinin değişimine neden olmaktadır. Teknolojide meydana gelen bu hızlı gelişimler bireylerin bilgileri yazılı kaynaklar yerine internet ortamından ulaşmasına olanak sağlamaktadır. Elde edilen bulgunun bir diğer nedeni olarak; öğretim programlarında ve öğretim ortamlarında teknolojik materyal kullanımının ön plana çıkması gösterilebilir. Eğitim öğretim döneminde bilgi edinme, araştırma yapma ve ödev yapma gibi faaliyetler için interneti kullanan bireylerin, ilerleyen dönemlerde de yaşamının her alanında teknoloji odaklı olduğu söylenebilir. Bu nedenle bireyler kütüphane ortamında bile bilgi erişiminde kitaplar ya da diğer yazılı kaynaklar yerine interneti tercih etmektedirler.

Çalışma sonucunda öğretmen adaylarının yaşam boyu öğrenme eğilimi motivasyonlarının yılda okudukları kitap sayısına göre anlamlı bir farklılık gösterdiği saptanmıştır. Yılda 15 ve üstü sayıda, yılda 6-14 arası sayıda, yılda 1-5 arası sayıda kitap okuyan öğretmen adaylarının yıl boyunca hiç kitap okumayan öğretmen adaylarına göre anlamlı derecede daha yüksek yaşam boyu öğrenme eğilimi motivasyonuna sahip oldukları sonucuna ulaşılmıştır. Aynı zamanda öğretmen adaylarının yılda okudukları kitap sayısı arttıkça yaşam boyu öğrenme eğilimi motivasyon puan ortalamalarının da arttığı belirlenmiştir. Okuma alışkanlığı bireylere araştırma, sorgulama, eleştirel düşünme, yeni bilgiler öğrenme isteği ve yaşam boyu öğrenme motivasyonu gibi nitelikler kazandırmaktadır (Güneyli, 2003). Okuma eylemi, çağdaş, düşünen, sorgulayan, eleştiren, yaşam boyu öğrenen bireyler oluşmasına olanak sağlamaktadır (Aksaçlıoğlu ve Yılmaz, 2007). Bu bağlamda bu araştırmadan elde edilen sonuçlara göre yıl boyunca daha çok sayıda kitap okuyan öğretmen adaylarının yıl boyunca hiç kitap okumayan öğretmen adaylarına göre daha yüksek yaşam boyu öğrenme eğilimi motivasyonu puan ortalamalarına sahip olmaları beklenilen bir sonuç olarak değerlendirilebilir.

Alanyazın incelendiğinde, Arı ve Demir (2013) yapmış oldukları çalışmada, ilköğretim bölümü öğretmen adaylarının yeterli düzeyde okuma alışkanlığına sahip olmadıkları; Mavi ve Çetin (2009) yapmış oldukları çalışmada beden eğitimi öğretmen adaylarının düşük düzeyde kitap okuma alışkanlığına sahip oldukları sonucuna ulaşmışlardır. Yılmaz (2002) Ankara'da görev yapmakta olan ilköğretim öğretmenleri ile yaptığı çalışmasında öğretmenlerin yetersiz bir okuma alışkanlığına sahip olduğu; Yılmaz (2009) çalışmasında çocukların yeterli ölçüde okuma alışkanlığına sahip olmadığı; Saracaloğlu, Yenice ve Karasakaloğlu (2009) çalışmalarında sınıf öğretmeni adaylarının düşük düzeyde okuma alışkanlıklarının olduğu sonucuna ulaşmıştır. Kurulgan ve Çekerol (2008) yapmış oldukları çalışmada ise üniversite öğrencilerinin yüksek düzeyde okuma alışkanlığına sahip oldukları sonucuna ulaşmıştır. 
Öğretmen adaylarının Yaşam Boyu Öğrenme Eğilimleri Ölçeğine ait “sebat" alt boyutu hariç tüm alt boyut ve toplam puanlarının kitap okumayı engelleyen faktörlere göre istatistiksel olarak anlamlı bir farklılık gösterdiği belirlenmiştir. Bu durum incelendiğinde; kitap okumak için zaman bulamadığını ifade eden öğretmen adaylarının Yaşam Boyu Öğrenme Eğilimi Ölçeği "motivasyon” alt boyutu ve "öğrenmeyi düzenleme" alt boyut puanları daha yüksek bulunmuştur. Derslerin yoğunluğundan dolayı kitap okumadığını ifade eden öğretmen adaylarının yaşam boyu öğrenme eğilimi "merak" alt boyut puanları daha yüksek tespit edilmiştir. Kitap okumanın ilgilerini çekmediğini belirten öğretmen adaylarının ise yaşam boyu öğrenme eğilimi ölçeği toplam puanları daha yüksek bulunmuştur. Sonuç olarak öğretmen adayları kitap okumayı engelleyen faktörler olarak zaman bulamadıklarını, derslerin yoğunluğunu ve kitap okumanın ilgi çekici olmadığını belirtmişlerdir. Öğretim programlarında yoğun kazanımlara yer verilmesi, sınav odaklı eğitim sisteminin uygulanması ve küçük yaşlarda bireylere okuma alışkanlığının kazandırımaması bu durumların başlıca ortaya çıkma nedenleri arasında gösterilebilir. Kitap okumayı engelleyen bu faktörleri ortadan kaldırmak için öğretim programlarına okuma faaliyetleri ve kitap okuma dersleri eklenebilir, aileler bu konuda bilinçlendirilerek bireylere küçük yaşta okuma alışkanlığı kazandırılabilir, kütüphane ve kitaplar daha ilgici şekilde planlanıp düzenlenebilir. Alanyazın incelendiğinde kitap okumayı engelleyen faktörleri farlı şekilde inceleyen çalışmalara rastlanılmıştır. Gönen ve diğerleri (2004) yaptıkları çalışmada kız ve erkek öğrencilerin boş zaman etkinliği olarak kitap okumayı toplamda \% 49,8 oranında tercih ettiklerini bulmuştur. Çetinkaya (2004), öğrencilerin boş zamanlarında çoğunlukla televizyon izlediklerini (\% 24,2) belirtmektedirler.

\section{ÖNERILER}

Elde edilen bulgular doğrultusunda bazı önerilere yer verilmiştir.

- Öğretmen adaylarına kütüphane alışkanlıklarını kazandırmak için lisans döneminde bu konuda projeler ve akademik çalışmalar yürütülebilir.

- Öğretmen adaylarının yaşam boyu öğrenme düzeylerini etkileyen diğer faktörler incelenebilir.

- Yapılan çalışma Türkiye'nin batı bölgesindeki bir üniversite ile sınırlıdır, daha büyük bir katılımcı grubu ile farklı bölgelerdeki üniversitelerde de çalışmalar yapılabilir.

\section{KAYNAKÇA}

Agaja, J.A. (1992). Childrens use of university of maiduguri staff primary school library. Education Libraries Journal, $35(1), 29$.

Aksaçlıoğlu, A.G. ve Yılmaz, B. (2007). Öğrencilerin televizyon izlemeleri ve bilgisayar kullanmalarının okuma alışkanlıkları üzerine etkisi. Türk Kütüphaneciliği, 2(1), 3-28.

American Library Association (ALA). (1978). Bookreading And Library Usage. A Study Of Habits And Perceptions. New Jersey: Gallup.

Arı, E. ve Demir, M. K. (2013). İlköğretim bölümü öğretmen adaylarının kitap okuma alışkanlıklarının değerlendirilmesi. Ana Dili Eğitimi Dergisi, 1(1), 116-128.

Atik Kara, D. ve Kürüm D. (2007). Sınıf öğretmeni adaylarının yaşam boyu öğrenme kavramına yükledikleri anlam (Anadolu Üniversitesi Eğitim Fakültesi Örneği) 16. Ulusal Eğitim Bilimleri Kongresi'nde sunulan bildiri (5-7 Eylül 2007). Gaziosmanpaşa Üniversitesi, Tokat.

Bagnall R.G. (2006). Lifelong learning and the limits of tolerance. International Journal of Lifelong Education, 25(3), 257-269.

Bağcı, Ş. E. (2007). Avrupa Birliği ülkelerinde yaşam boyu eğitim politikaları Almanya, Danimarka ve Türkiye üzerine karşılaştırmalı bir çalışma. Yayınlanmamış Yüksek Lisans Tezi, Ankara Üniversitesi, Ankara.

Bekar, Ü. (2005). Ilköğretim birinci sınıf öğrencilerinin okuma alışkanlığı kazanmalarında ailenin Rolü. Yayınlanmamış Yüksek Lisans Tezi, Gazi Üniversitesi Eğitim Bilimleri Enstitüsü, Ankara.

Belet, S.D. ve Yasar, S. (2007). Öğrenme stratejilerinin okuduğunu anlama ve yazma becerileri ile Türkçe dersine ilişkin tutumlara etkisi. Eğitimde Kuram ve Uygulama, 3(1), 69-86.

Berberoğlu, B. (2010). Yaşam boyu öğrenme ile bilgi ve iletişim teknolojileri açısından Türkiye'nin Avrupa Birliği'ndeki konumu. Bilgi Ekonomisi ve Yönetimi Dergisi, 5(2), 113-126.

Budak, Y. (2009). Yaşam boyu öğrenme ve ilköğretim programlarının hedeflemesi Gereken İnsan Tipi. Gazi Eğitim Fakültesi Dergisi, 29(3), 693708.

Büyüköztürk, Ş., Kılıç Çakmak, E., Akgün, Ö.E., Karadeniz, Ş. ve Demirel, F. (2008). Bilimsel araştırma yöntemleri. Ankara: Pegem Yayınları.

Candy, P. C. (2003). Lifelong learning and information literacy. Report for U.S national commission on libraries and information Science and National Forum on Information Literacy.

Çetinkaya, Ç. S. (2004). Afyon merkezindeki ilköğretim 8.sınıf öğrencilerinin okuma alışkanlığı. Yayınlanmamış Yüksek Lisans Tezi, Afyon Kocatepe Üniversitesi, Afyon.

Coşkun, E., Nohutçu, A. ve Balcı, A. (2007). Lise Birinci Sınıf Öğrencilerinin Okuma İlgi ve Alışkanlıkları Üzerine, ICANAS, 38(38), 10-15.

Coşkun Diker, Y. (2009). Üniversite öğrencilerinin yaşam boyu öğrenme eğilimlerinin bazı değişkenler açısından incelenmesi. Yayınlanmamış Doktora Tezi, Hacettepe Üniversitesi, Ankara.

Demiralay, R. ve Karadeniz, Ş. (2008). İlköğretimde yaşam boyu öğrenme için bilgi okuryazarlığı becerilerinin geliştirilmesi. Cypriot Journal of Educational Sciences, 6, 89-108.

Demirel, Ö. (1999). Türkçe Öğretimi. Ankara: PegemA Yayıncılık. 
Dengiz, A. Ş. ve Yılmaz, B. (2007). 2004 İlköğretim Programı'nda okuma ve kütüphane kullanma alışkanlıklarına ilişkin öğretmen görüşleri. Bilgi Dünyası, 8(2), 203-229.

D. P. T. (2006). Dokuzuncu kalkınma planı (2007-2013). Ankara: Başbakanlık Devlet Matbaası HYPERLINK "http://ekutup. dpt. gov. tr/plan9. pdf" http://ekutup. dpt. gov. tr/plan9. pdf "Retrieved from" June, 15, 2018.

Doğanay, H. (2001). Halk kütüphanelerinin okuma alıskanlığındaki rolü ve önemi. Türk Kütüphaneciliği 15(1), 40-44.

Dökmen, Ü. (1990). Lise ve üniversite öğrencilerinin okuma becerileri, ilgileri, okuma ve kütüphane kullanma alışkanlıkları. Eğitim Bilimleri Dergisi, 23(2), 395-418.

Ersoy, A. ve Yılmaz, B. (2009). Yaşam boyu öğrenme ve Türkiye'de halk kütüphaneleri. Türk Kütüphaneciliği, 23(4), 803-834.

Field, A. (2009). Discovering statistics using SPSS (3 ${ }^{\text {rd }}$ edition). London: Sage Publications.

Göğüs, B. (1978). Orta dereceli okullarımızda türkçe ve yazın eğitimi. Ankara: Gül Yayınevi.

Gönen, M., Öncü, E. ve Isıtan, S. (2004). İlköğretim 5. 6.ve 7. sınıf öğrencilerinin okuma alışkanlıklarının incelenmesi. Milli Eğitim Dergisi, 164, 824.

Güneyli, A. (2003). Metin türlerine göre okuduğunu anlama becerisinin sınanması (Türkiye-Kuzey Kıbrıs Türk Cumhuriyeti Üniversiteleri üzerinde bir araştırma). Yayınlanmamış yüksek lisans tezi, Ankara Üniversitesi Sosyal Bilimler Enstitüsü, Ankara.

Gürdal, O. (2000). Yaşam boyu öğrenme etkinliği: Enformasyon okuryazarlığı. Türk Kütüphaneciliği, 14, 176-187.

Haseski, H. I., Şahin, Y.L., Yılmaz, E. ve Erol, O. (2014). Facebook kullanım amaçları ile yaşam boyu öğrenme eğilimleri arasındaki ilişkinin incelenmesi. Eğitimde Kuram ve Uygulama, 10(2), 331-351.

Karakuş, C. (2013). Meslek yüksek okulu öğrencilerinin yaşam boyu öğrenme yeterlikleri. Eğitim ve Öğretim Araştırmaları Dergisi, 2(3), 26-35.

Karasar, N. (2014). Bilimsel araştırma yöntemi (27. basım). Ankara: Nobel Akademik Yayıncılık.

Kaya, H.E. (2010). Avrupa Birliği yaşam boyu öğrenme ve yetişkin eğitimi politikaları. Yayınlanmamış Doktora Tezi, Ankara Üniversitesi Eğitim Bilimleri Enstitüsü, Ankara.

Keleş, Ö. (2006). Illköğretim 4. ve 5. sınıf öğrencilerinde kitap okuma alışkanlığının incelenmesi. Yayınlanmamış Yüksek Lisans Tezi. Gazi Üniversitesi, Eğitim Bilimleri Enstitüsü.

Kılıç, H. ve Tuncel, A. Z. (2014). İlköğretim branş öğretmenlerinin bireysel yenilikçilik düzeyleri ve yaşam boyu öğrenme eğilimleri. Uluslararası Eğitim Programları ve Öğretim Çalışmaları Dergisi, 4(7), 25-37.

Koç, G. (2007). Yaşam boyu öğrenme. Özcan Demirel (Ed.), Eğitimde yeni yönelimler içinde (209-222). Ankara: PegemA Yayıncılık.

Kulich, J. (1982). Lifelong education and the universities: A canadian perspective. International Journal of Lifelong Education, 1(2), $123-142$.

Kurbanoğlu, S. (2010). Bilgi okuryazarlığı: Kavramsal bir analiz. Türk Kütüphaneciliği, 24(4), 723-747.

Kurulgan, M. ve Çekerol, G. S. (2008). Öğrencilerin okuma ve kütüphane kullanma alışkanlıkları üzerine bir araştırma. Anadolu Üniversitesi Sosyal Bilimler Dergisi, 8(2), 237-258.

Mavi, H. F. ve Çetin, B. (2009). Beden eğitimi öğretmen adaylarının kitap okumaya ilişkin görüş ve tutumlarının değerlendirilmesi. Beden Eğitimi ve Spor Bilimleri Dergisi, 4(1), 1-11.

Milli Eğitim Bakanlığı (MEB). (2017). Illköğretim Fen ve Teknoloji Dersi (6, 7, 8. Sınıflar) Öğretim Programı. Ankara: MEB Yayınları.

Odabaş, H., Odabaş, Z. Y. ve Polat, C. (2008). Üniversite öğrencilerinin okuma alışkanlığı: Ankara Üniversitesi örneği. Bilgi Dünyası, 9(2), 431-465.

Özbay, M. (2007). Türkçe Özel Öğretim Yöntemleri (2.Baskı), Ankara: Öncü Yayınevi.

Rausch, A. S. (2003). A case of lifelong in Japan: Objectives cirriculum, accountability and visibility. International of Lifelong Education, 22(5), 518532.

Saracaloğlu, A.S., Yenice, N. ve Karasakaloğlu, N. (2009). Öğretmen adaylarının iletişim ve problem çözme becerileri ile okuma ilgi ve alışkanlıkları arasındaki ilişki. Yüzüncü Yıl Üniversitesi Eğitim Fakültesi Dergisi, 6(2), 166-185.

Selvi, K. (2011). Öğretmenlerin yaşam boyu öğrenme yeterlikleri. Uluslararası Eğitim Programları ve Öğretim Çalışmaları Dergisi, 1(1), 61-69.

Soran, H., Akkoyunlu, B. ve Kavak, Y. (2006). Yaşam boyu öğrenme becerileri ve eğiticilerin eğitimi programı: Hacettepe üniversitesi örneği. Hacettepe Üniversitesi Eğitim Fakültesi Dergisi, 30, 201-210.

Thompson, J. (2001). Rerooting lifelong learning. Leicester: niace.

Türk Dil Kurumu (TDK). (1992). Alışkanlık. Türkçe Sözlük İçinde. İstanbul.

Tortop, Ö. (2010). Avrupa Birliği hayat boyu öğrenme temel yeterlik alanları: Türkiye durumu. Yayınlanmamış Yüksek Lisans Tezi, Gazi Üniversitesi, Ankara.

Uysal, M. (2009). Adult education in developed countries. International Journal of Educational Policies, 3(2), 17-23.

Yıldız, A. (2013). Türkiye'de öğretmenlik mesleğinin dönüşümü: İdealist öğretmenden sınava hazırlayıcı teknisyen öğretmene. Eleştirel Pedagoji Dergisi, 5(27), 43-50.

Yılmaz, B. (2002). Ankara'daki ilköğretim öğretmenlerinin okuma ve halk kütüphanesi kullanma alışkanlıkları üzerine bir araştırma. Türk Kütüphaneciliği, 16(4), 441-460.

Yılmaz B. (2004). Öğrencilerin okuma ve kütüphane kullanma alışkanlıklarında ebeveynlerin duyarlılığı. Bilgi Dünyası, 5(2), 115-136.

Yılmaz, B. (2009). Çocuklarda okuma kültürünü geliştirmede ebeveyn ve öğretmenin rolü. Çocuk ve Okuma Kültürü Sempozyumu, $133-140$. 